\title{
The Women Entrepreneurs Failure Factors in the Case of Gojjam
} Zones

\author{
Getaneh Yenealem Ayene Nebyu Adamu Abebe \\ College of Business and Economics, Department of Accounting and Finance, Debre Markos University, \\ P. O.Box 269, Debre Markos Ethiopia
}

\begin{abstract}
This study was designed to assess the Women Entrepreneurs Failure Factors in the Case of Gojjam Zones. In particular the study investigated how Individual reason, Competition, General environment and corporate policy affect women entrepreneurs in small businesses. Therefore to understand and analyze business failure factors a case of Women Entrepreneurs in the case of Gojjam Zones, the researchers have adopted a quantitative research approach. The researcher collects data through questioner. Information from the participants was analyzed by using statistical package for social sciences. For this study the target populations are business companies operating in Gojjam Zones for the last five years (from 2006-2010 as of Ethiopian Calendar). Do you to data unavailability we failed to know exactly the number of women owned/managed business in the two zones/West Gojjam \& East Gojjam/, the Sample Size of this study is determined using Infinite Population (where the population is greater than $50,000)$ sample size determination formula of Godden, (2004). Based on the formula A sample of 384 women entrepreneurs was chosen for the study. Both tables and frequency distributions were utilized to draw valid conclusions. From the study that individual characteristics/Motivations, managerial skills, knowledge \& experience, and fear of failure/ of a woman were statistically significant at $5 \%$ level of significance. And hence immediate environment factors are significant at $5 \%$ level of significance and thus these variables have an effect on women entrepreneurs' business failure. But availability of infrastructure and government incentives were found to be statistically insignificant. Finally depicts existence of marketing strategy, financing strategy incentives to motivate employees, and cooperation among partners are statically significant at $5 \%$ level of significance thus they have an effect on business failure. However, withdrawal of a partner is not a significant variable.
\end{abstract}

Keywords: Ethiopian, Entrepreneurs, failure factors, Women, business

DOI: $10.7176 / \mathrm{JCSD} / 61-02$

Publication date:September $30^{\text {th }} 2020$

\subsection{Background of the Study}

Entrepreneurship is more and more recognized as a very important driver of economic process, productivity, innovation and employment, and it's wide accepted as a key side of economic dynamism. remodeling concepts into economic opportunities is that the decisive issue of entrepreneurship. History shows that economic progress has been considerably advanced by pragmatic those that area unit entrepreneurial and innovative, able to exploit opportunities and willing to require risks (Hisrich, 2005).

The role of entrepreneurship associated an entrepreneurial culture in economic and social development has modified over years and it's become more and more apparent that entrepreneurship so contributes to economic development. nonetheless, the many numbers of enterprises were closely-held by men (ILO, 2006). In alternative words, it absolutely was not common to check women-owned businesses worldwide particularly in developing countries like African nation. the thought and observe of girls entrepreneurship may be a recent development. till the 1980's very little was identified regarding girls entrepreneurship each in observe and analysis, that created its focus entirely on men. Scientific discourse regarding women's entrepreneurship and girls closely-held and run organizations is simply the event of Eighties (ILO, 2006)

According to World Bank development indicators report as cited in Kipnis,2013 girls in African nation represent regarding half the population, initiatives that support women's economic authorisation area unit vital to the country's economic development. The Ethiopian Government adopted a National Policy on Ethiopian girls in 1993 with the aim of eliminating gender and cultural biases that hinder girls from taking part equally within the economic development of the country. In 2000, African nation took steps towards supporting women's economic activities by reforming its family law, eliminating a husband's ability to deny permission for his woman to figure outside the house, and requiring each spouses to agree in administering family property. These changes have shifted women's economic activities toward occupations involving higher skills, longer work hours, and additional choices to figure outside the house. Today, girls represent forty seven p.c of the force, and 81percent of girls participate within the labor, compared to ninety p.c of men. the bulk of girls add the informal sector, representing sixty p.c of informal enterprise homeowners.

Most of girls engaged in formal business (those recognized by trade and transport office) area unit presently engaged in Medium, tiny and small Enterprises (MSME). MSME sector in \{ethiopia|Ethiopia|Federal Democratic Republic of African nation|Yaltopya|Abyssinia|African country|African nation\} provides keep to forty ninth of all 
utilized girls in Ethiopia. therefore this sector needs vital support from government policies and laws as they contribute considerably to the economy in terms of job creation, skills development and also the alleviation of abject poorness. additionally owner's business skills, handiness of finance, applicable business trainings, and market matter most for his or her survival. (Eshetu and Zeleke, 2008)

\subsection{Statement of The Problem}

Research conducted by the World Bank (2005), the World Trade Organization (2002), the Ministry of Finance and Economic Development of Ethiopia (2002) according to Eshetu and Zeleke(2008), women entrepreneurs in Ethiopia initiate new businesses and enterprises at a rate doubly as fast as men, which they notice it tougher at the point to grow their business to future higher level. Survival of a firm is outlined because the ability of the firm to continue its operation and stay in business throughout an explicit amount of your time in an exceedingly competitive.

In addition analysis findings of Eshetu and Zeleke (2008) on key determinants of survival between 1996 and 2001 shows that $22 \%$ of business had failed within five years, of that the majority of businesses failed were operated by women (78\%). Female-headed companies that ceased operation had an average lifetime of 3.20 years, whereas male-headed companies that ceased operation had an average lifetime of 3.90 years. They ended that businesses operated by women were 2.52 times more likely to fail in comparison with businesses operated by men. This may raise the question why feminine headed business simply fail as compared to male headed business where as women are smart at making new business doubly as fast as men. Thus knowing the basis can will increases women's role in the economy. Therefore, this study seeks to answer: what factors contribute to women Entrepreneurs/business to fail?

\subsubsection{Research Questions}

The following are the research questions:

1. What are the major internal causes of business failure?

2. What are the major external causes of business failure?

3. Do failure factors differ significantly between successful \& failed business?

4. Do failure factors significantly vary among different sizes of companies?

\subsection{Objectives of the Study}

The main objective of this study is to identify Women Entrepreneurs failure factors in the case of Gojjam Zones This study has the following specific objectives

1. To assess internal factors causing business to fail.

2. To identify major external factors causing business to fail.

3. To identify factors which differ significantly between operational \& failed business.

4. To investigate whether factors identified significantly vary among sizes of companies.

\section{Literature review}

\subsection{An overview to entrepreneurship}

As globalisation reshapes the international economic landscape and technological amendment creates larger uncertainty within the world economy, the dynamism of entrepreneurship is believed to be able to facilitate to satisfy the new economic, social and environmental challenges. Governments more and more take into account entrepreneurship and innovation to be the cornerstones of a competitive financial system, and in most countries entrepreneurship policies area unit in truth closely connected to innovation policies, with that they share several characteristics and challenges. The dynamic method of recent firm creation introduces and disperses innovative product, processes and structure structures throughout the economy. Entrepreneurship objectives and policies yet dissent significantly among countries, attributable to completely different policy wants and various views on what's meant by entrepreneurship. In support of this Joseph Schumpeter (2005) declared that:

In some countries, entrepreneurship is coupled to regional development programs and therefore the creation of latest companies is stirred to spice up employment and output in depressed regions. In others, entrepreneurship may be a key component of methods designed to facilitate the participation of sure target teams, like ladies or minorities, within the economy. Some countries merely look for to extend firm creation in and of itself, whereas others embarked on to support high-growth companies. whereas several countries area unit creating serious efforts to support entrepreneurship, results seem to vary. Countries wish to know the determinants of and obstacles to entrepreneurship, and that they got to analyse the effectiveness of various policy approaches (pp.)

The lack of internationally comparable empirical proof has but affected our understanding of entrepreneurship and plenty of queries stay unrequited. Ultimately, affairs of state should be radio-controlled, as way as attainable, by proof and facts.

According to Ponstadt (1998) Entrepreneurship is that the dynamic method of making progressive wealth. This wealth is formed by people UN agency assume the foremost risks in terms of equity, time and/or career 
commitments of providing values for a few product or service. the merchandise or service may/may not be new or distinctive however worth should be infused by the businessperson by securing and allocating the required skills and resources.

Furthermore, Timmons (1989) outlined it in such how that: Entrepreneurship is that the method of making and building one thing important from much nothing. That is, it's the method of making or seizing a chance and following it in spite of the resources presently controlled. It involves the definition, creation and distribution of values and edges to people, groups, organizations and society. Entrepreneurship is extremely seldom a get richquick proposition (not short term); rather it's one amongst building long run worth and sturdy income streams.

In addition, Hisrich (2005 :) outlined entrepreneurship as follows: Entrepreneurship is that the method of making one thing new with worth by devoting the required time and energy, presumptuous the concomitant money, psychic, and social risks, and receiving the ensuing rewards of financial and private satisfaction and independence. From the definitions given higher than, it's potential to conclude that in the majority of the definitions of entrepreneurship, there's agreement that we tend to area unit talking a few quite behaviour that includes: (1) initiative taking, (2) the organizing and reorganizing of social and economic mechanisms to show resources and things to sensible account, (3) the acceptance of risk or failure.

\subsection{Factors affecting entrepreneurship}

Even though entrepreneurship has its own blessings, it's not freed from issues. For this there are variety of things .Samiti (2006), Tan (2000) classified the fundamental factors that have an effect on entrepreneurs in to 2 broad classes -economic and social. The economic factors embrace competition within the market; lack of access to the market ,lack of access to stuff, lack of capital or finance, lack of selling knowledge; lack of production/ storage space; poor infrastructure; inadequate power provide and lack of business coaching.

The social factors embrace lack of social acceptability; having restricted contacts outside prejudice and sophistication bias; society appearance down upon; angle of alternative employees; and relations with the manpower. Besides this, Gemechis (2007), Hisrich (2005), International Labor Organization (2009) extra Social and cultural angle towards youth entrepreneurship; entrepreneurship education; body and restrictive framework; and business help and support; barriers to access technology ar crucial factors that have an effect on entrepreneurial success.

\subsection{Women entrepreneurship}

Women's productive activities, notably in industry, empower them economically and change them to contribute additional to overall development. whether or not they area unit concerned in little or medium scale production activities, or within the informal or formal sectors, women's entrepreneurial activities don't seem to be solely a way for economic survival however even have positive social repercussions for the ladies themselves and their surroundings. United Nations Industrial Development Organization (UNIDO, 2001).

In several societies girls don't relish identical opportunities as men. In several transmutation economies progress has been achieved in gap doors to education and health protection for ladies however political and economic opportunities for feminine entrepreneurs have remained restricted. united efforts area unit required to change feminine entrepreneurs to form higher economic decisions and to rework their businesses into competitive enterprises, generating financial gain and employment through improved production (OECD, 1997).

\subsection{Factors affecting women entrepreneurs' performance}

Women Entrepreneurs have full-grown in sizable amount across the world over the last decade and more and more the entrepreneurial potentials of Women have modified the agricultural economies in several components of the world. However this doesn't mean that the issues are wholly resolved. In support of this a review by Desta Solomon (2010), ILO (2006) and Yeshiareg Dejene known the subsequent factors that have an effect on Women entrepreneurs.

\section{A. Access to finance}

The average level of collateral required for a loan (173\% in 2006) by banks is one of the highest in the developing world (WB 2009). It is more difficult to access finance for capital expenditure than for working capital. Access to finance is rated as one of the top three problems ( $60 \%$ of firms) by micro, small medium and large firms surveyed by the WB. Access to finance for

MSEs is mediated through micro finance institutions since the collateral requirements of commercial banks exclude most MSEs from accessing finance from these sources. The majority of the need for business finance is met through individual savings and other informal sources and supplier credit. Access to financial services for vertical growth and diversification of activities is very limited. Micro Finance Institutions cater mainly for the lower ('economically active poor') echelon of clients while banks cater for medium and large enterprises. The growth-oriented micro and small enterprises on the one hand and the poorest on the other are not catered for. Sources of finance for women entrepreneurs are mainly informal (Equb, individual savings, borrowing from family 
and friends), micro finance institutions and banks. The main source of finance for starting up and expansion of women- owned enterprises is from the women's own savings (such as through Equb), loans, and contributions from family and friends.

Once in businesses women entrepreneurs' access to finance becomes a very severe constraint as individual savings are not enough for expansion and the profit generated is not large enough to allow for growth and expansion (Desta Solomon, 2010).

\section{B. Access to markets}

The ability to tap into new markets needs experience, data and contacts. Women typically lack access to coaching and knowledge in on a way to participate within the market place and square measure thus unable to plug merchandise and services strategically. Thus, women-owned SMEs square measure typically unable to require on each the assembly and selling of their merchandise. Additionally, they need typically not been exposed to the international market, and thus lack data concerning what's internationally acceptable. The high value of developing new business contacts and relationships during a new country or market could be a huge deterrent and obstacle for several SMEs, specifically women-owned businesses. girls might also worry or face prejudice or harassment, and should be restricted in their ability to jaunt create contacts (UNECE, 2004).

\section{Access to coaching}

Studies have indicated that Women usually less educated than men within the small enterprise sector however their level of education is best within the tiny and medium enterprise sector. Access to coaching opportunities for MSEs is extremely restricted despite the very fact that many NGOs, donors and government bodies do give coaching. Access to place coaching and on-the-job experiences is additionally terribly restricted whereas different services like business extension services and counsel square measure usually untouchable for MSEs. The most vital sources of data for MSEs square measure customers, suppliers, relatives and friends, non-competing similar businesses, and competitors. data provided by establishments (such as government, chambers of commerce, etc.) is tough to access or of very little use to MSEs The coaching isn't versatile in terms of the delivery schedule, location and language to accommodate the precise challenges that lady entrepreneurs face as mothers and carers and conjointly coaching sessions square measure happening events and also the indisputable fact that several of the trainers square measure men could be a major barrier Women entrepreneurs (because Women like Women trainers and husbands don't like women to be trained by men trainers); (Desta king, 2010).

\section{Access to networks}

Women have fewer business contacts, less data of a way to agitate the governmental paperwork and fewer negotiation power, all of that more limit their growth. Since most ladies entrepreneurs care for alittle scale, and square measure usually not members of skilled organizations or a part of different networks, they typically realize it tough to access data. Most existing networks square measure male dominated and typically not significantly hospitable to girls however like better to be exclusive. Even once a lady will venture into these networks, her task is usually tough as a result of most network activities turn up once regular operating hours. There square measure hardly any women-only or women-majority networks wherever a lady may enter, gain confidence and move more.

\section{E. Culture}

Culture was a big issue touching the success of girls entrepreneurs. As shown in Figure one on top of, fourhundredth of the respondents indicated that as ladies they're expected to require up roles within the home instead of within the business world. Some male counterparts feel vulnerable if ladies have interaction in business and generate cash and take up roles as breadwinners. it absolutely was established that male counterparts didn't support ladies in their businesses. but hr of the respondents indicated that such cultural aspects were superannuated as their male counterparts required facilitate in generating funds for the up-keep of the family. per Calas and Smirnich (1992) cited by Morris et al. (2006), culturally obligatory attitudes concerning gender stay barriers to ladies in achieving higher money rewards and standing within the business world.

\section{F. Risk taking}

Of the whole respondents fifty fifth of girls entrepreneurs cited that they weren't able to assume a great deal of risk as a result of their gender limitations. therefore they might not venture into risky businesses. These results were per those of geological formation (1998) cited by Yordanova (2011) and Adoram (2011) who found out that most women tended to be more risk averse. Morris et al (2006) distinguished that whereas usually assured, these entrepreneurs were a lot of risk disinclined and lots of felt an exact inadequacy in terms of their backgrounds.

\section{Research Methods}

According to Creswell (2003) the problem that's going to be investigated within the study is employed as a base for decisive the analysis approach. If the problem is distinguishing factors that influence associate degree outcome, the utility of associate degree intervention or understanding the simplest predictors in outcomes, then a quantitative approach is best. Thus to know and analyze business failure factors a case of women Entrepreneurs within the case of Gojjam Zones, the analysisers have adopted a quantitative research approach. Under this approach, analysis is created supported deduction, starting with bound theory or hypotheses and drawing logical conclusions from it. 
what is more it's vital to eliminate or minimize judgement of judgment; follow firmly the initial set of analysis goals, incoming at additional objective conclusions. (Balsley, 1970)

\subsection{Sampling style}

For this study the target populations are business firms operative in Gojjam Zones for the last 5 years (from 20062010 as of Ethiopian Calendar). does one to knowledge inconvenience we have a tendency to didn't recognize precisely the range of women owned/managed business within the two zones/West Gojjam \& East Gojjam/, the Sample Size of this study is using Infinite Population (where the population is bigger than 50,000) sample size determination formula of Godden, (2004).

$$
\mathrm{n}=\frac{\mathrm{z}^{2} . \text { P.q. }}{\mathrm{e}^{2}}
$$

Where:

$\mathrm{n}=$ Size of Sample;

$\mathrm{P}=$ reasonable estimate for the key proportion to be studied;

$\mathrm{q}=1-\mathrm{p}$

$\mathrm{z}=$ standard deviation at $95 \%$ confidence level $(\mathrm{z}=1.96)$; and

$\mathrm{e}=$ acceptable error $(\mathrm{e}= \pm 0.0464)$.

Hence, $n=\frac{(1.96)^{2} \times 0.5 \times 0.5=384}{(0.05)^{2}}$

$$
(0.05)^{2}
$$

Thus data is going to be collected from 384 randomly selected samples from six town administrations; three from each zones (namely; Debre Markos, Dejen, \& Bichena from East Gojjam Zone and Dembecha, Fnote Selam \& Bure from West Gojjam Zone.) The sample companies in each town would be prorated in proportion to the number of women owned/managed business.

So as to select each business company we have proposed to use snowball sampling technique for nonoperational business owners and random sampling technique for business in operation.

\subsection{Data Source, Collection and Method of Analysis}

To meet the objective of the study the researchers primarily proposed to use primary data and secondary source of data is also to be used to some extent to get support findings. Primary data are to be gathered by questionnaires based on Ooghe and De Prijcker's (2008) model (in five-point Likert) which ask questions around four elements including: general environment, immediate environment, manager/entrepreneur, and corporate policy. After checking the validity of the questionnaire to be used in this study using measurement of Cronbach's alpha, Data collected will be analyzed using descriptive statistics through the help of SPSS/Statistical Software Package for Social Science/. Open ended questions will also be analyzed based on thematic areas. We used various statistical tests depending on the nature of data to identify significant business failure factors.

\subsection{Variable Description and Measurement}

Variables that explain business failure can be firm specific, industry specific, macro-economic specific and spatial or geographic factors (Maoh \& Kanaroglou , 2007). Ooghe and De Prijcker (2008) classified causes of bankruptcy into four groups of factors:

(1) General environment (economic, technology, foreign countries, politics, and social factors),

(2) Immediate environment (customers, suppliers, competitors, banks and credit institutions, stockholders, and misadventure),

(3) Manager/entrepreneur (motivation, qualities, skills, and characteristics) and

(4) Corporate strategy (strategy and investments, operations, personnel, and administration).

For this research we have proposed o use Ooghe and De Prijcker (2008) model and the variables used are described below in table: 


\begin{tabular}{|l|l|l|}
\hline Dimensions & Variables & Explanations \\
\hline \multirow{4}{*}{ Individual } & Lack of motivations & Motivation over time \\
\cline { 2 - 3 } & Lack of skills & Management marketing skills \\
\cline { 2 - 3 } & Lack of capabilities & Knowledge \& Experience \\
\cline { 2 - 3 } Immediate & $\begin{array}{l}\text { Inappropriate } \\
\text { characteristics }\end{array}$ & Attitude, family \& psychological pressures \\
\hline \multirow{4}{*}{$\begin{array}{l}\text { General } \\
\text { environment }\end{array}$} & Customers issues & Customers preference, \& related issues \\
\cline { 2 - 3 } & Suppliers issues & Accessibility \& Suppliers power \\
\cline { 2 - 3 } & Intensity of competition & Level of sectoral competition \\
\cline { 2 - 3 } & Creditors issues & Accessibility \& cost of credit \\
\hline \multirow{5}{*}{ Corporate policy } & Economic situation & Stability of economy, inflation, interest rate \\
\cline { 2 - 3 } & Changing technology & Use \& cost of new technology \\
\cline { 2 - 3 } & Inappropriate policies & Stability of rules, support of entrepreneurs \\
\cline { 2 - 3 } & Social factors issues & Role models, societal view on entrepreneurship, culture \\
\cline { 2 - 3 } & Strategy and investments & Sales model, pricing \& business financing strategies, \\
\cline { 2 - 3 } & Staff issues & Staff motivation, skill \& cost of labor \\
\cline { 2 - 3 } & Partnership issues & Exit of partner, cooperation's \& rust among partners, \\
\cline { 2 - 3 } & Executive issues & $\begin{array}{l}\text { Inappropriate financial management, marketing evaluation, } \\
\text { assessment of duties, awareness about laws etc }\end{array}$ \\
\hline
\end{tabular}

After collecting all relevant data two independent sample chi-square test will be used to analyze the differences in viewpoints of operational versus failed entrepreneurs. Friedman test will also be used to compare mean ranking of two groups of entrepreneurs.

\section{Analysis of Data \& Presentation of Results}

In this section findings collected from respondents has been presented using different stastical tools.

\subsection{Demographic Characteristics of Respondents}

As shows in table 4.1 Most of the respondents $/ 89.8 \%$ / were less than 30 years old and $68 \%$ of the respondents have completed secondary education. Only few number of the respondents (18\%) completed technical and university education. About $64 \%$ of the respondents were married women respondents. Almost all $/ 98 \% /$ of women entrepreneurs were engaged in merchandising business in which majority of business owners have employed less than five employees. When the ownership structure is taken in to account all of the participants were sole proprietors and about $85 \%$ of the entrepreneurs' were earning an average annual income of less than ETB 30,000. Table 4.1. Frequency Table for demographic characteristics of respondents

\begin{tabular}{|c|c|c|c|c|c|}
\hline \multicolumn{2}{|l|}{ Age } & Frequency & Percent & Valid Percent & Cumulative Percent \\
\hline $\begin{array}{l}\text { Valid } \\
\text { Total }\end{array}$ & $\begin{array}{l}<30 \text { Years } \\
31-40 \text { Years } \\
41-50 \text { Years }\end{array}$ & \begin{tabular}{|l|}
345 \\
23 \\
16 \\
384 \\
\end{tabular} & $\begin{array}{l}89.8 \\
6.1 \\
4.1 \\
100.0 \\
\end{array}$ & $\begin{array}{l}89.8 \\
6.1 \\
4.1\end{array}$ & $\begin{array}{l}89.8 \\
95.9 \\
100.0\end{array}$ \\
\hline Educa & nal Level & Frequency & Percent & Valid Percent & Cumulative Percent \\
\hline Valid & $\begin{array}{l}\text { Primary Education } \\
\text { Secondary Education } \\
\text { Vocational Education } \\
\text { University Level } \\
\text { Total }\end{array}$ & $\begin{array}{l}54 \\
261 \\
54 \\
15 \\
384 \\
\end{array}$ & $\begin{array}{l}14.0 \\
68.0 \\
14.0 \\
4.0 \\
100.0\end{array}$ & $\begin{array}{l}14.0 \\
68.0 \\
14.0 \\
4.0 \\
100.0 \\
\end{array}$ & $\begin{array}{l}14.0 \\
82.0 \\
96.0 \\
100.0\end{array}$ \\
\hline Marit & status & Frequency & Percent & Valid Percent & Cumulative Percent \\
\hline $\begin{array}{l}\text { Valid } \\
\text { Total }\end{array}$ & $\begin{array}{l}\text { Unmarried } \\
\text { Married }\end{array}$ & $\begin{array}{l}137 \\
247 \\
384 \\
\end{array}$ & $\begin{array}{l}35.6 \\
64.4 \\
100.0\end{array}$ & $\begin{array}{l}35.6 \\
64.4\end{array}$ & $\begin{array}{l}35.6 \\
100.0\end{array}$ \\
\hline Types & f business & Frequency & Percent & Valid Percent & Cumulative Percent \\
\hline Valid & $\begin{array}{l}\text { Manufacturing } \\
\text { Trade } \\
\text { Total }\end{array}$ & $\begin{array}{l}8 \\
376 \\
384 \\
\end{array}$ & $\begin{array}{l}2.0 \\
98.0 \\
100.0\end{array}$ & $\begin{array}{l}2.0 \\
98.0 \\
100.0\end{array}$ & $\begin{array}{l}2.0 \\
100.0\end{array}$ \\
\hline
\end{tabular}




\begin{tabular}{|c|c|c|c|c|}
\hline Time engaged in the business & Frequency & Percent & Valid Percent & Cumulative Percent \\
\hline$<5$ Years & 346 & 90.0 & 90.0 & 90.0 \\
\hline 5-7 Years & 15 & 4.0 & 4.0 & 94.0 \\
\hline 7-9 Years & 23 & 6.0 & 6.0 & 100.0 \\
\hline Total & 384 & 100.0 & & 100.0 \\
\hline
\end{tabular}

\begin{tabular}{|c|c|c|c|c|}
\hline No. of employees & Frequency & Percent & Valid Percent & Cumulative Percent \\
\hline $\begin{array}{ll}\text { Valid } & <5 \\
\text { Total } & 5-10\end{array}$ & $\begin{array}{l}346 \\
8 \\
50 \\
\end{array}$ & $\begin{array}{l}98 \\
2.0 \\
100.0\end{array}$ & $\begin{array}{l}98 \\
2.0\end{array}$ & $\begin{array}{l}98 \\
100.0\end{array}$ \\
\hline Ownership status & Frequency & Percent & Valid Percent & Cumulative Percent \\
\hline Valid $\quad$ Sole & 384 & 100.0 & 100.0 & 100.0 \\
\hline Annual revenue & Frequency & Percent & Valid Percent & Cumulative Percent \\
\hline $\begin{array}{ll} & <\operatorname{Br} 20,000 \\
& \operatorname{Br} 21,000-30,000 \\
\text { Valid } & \operatorname{Br} 31,000-40,000 \\
& \operatorname{Br} 41,000-50,000 \\
& >\operatorname{Br} 51,000 \\
\text { Total } & \end{array}$ & $\begin{array}{l}79 \\
251 \\
23 \\
23 \\
8 \\
50\end{array}$ & $\begin{array}{l}20.4 \\
65.3 \\
6.1 \\
6.1 \\
2.0 \\
100.0\end{array}$ & $\begin{array}{l}20.4 \\
65.3 \\
6.1 \\
6.1 \\
2.0\end{array}$ & $\begin{array}{l}20.4 \\
85.7 \\
91.8 \\
98.0 \\
100.0\end{array}$ \\
\hline
\end{tabular}

Source: Survey 2019

Test of Validity and Reliability

Content validity of the questionnaire on the causes of business failure was estimated by submitting the questionnaire to several academicians in the business disciplines, all of whom approved the content of the questionnaire. To test the reliability, the internal consistency of the questionnaire was assessed by Cronbach's alpha coefficient that was 0.891 for the questionnaire on the causes of business failure, and alpha equal to or greater than 0.70 was considered satisfactory.

Table 4.2: Reliability Test

Case Processing Summary

\begin{tabular}{|ll|l|l|}
\hline & & $\mathrm{N}$ & $\%$ \\
\hline \multirow{4}{*}{ Cases } & Valid & 323 & 84.0 \\
& Excluded $^{\mathrm{a}}$ & 61 & 16.0 \\
& Total & 384 & 100.0 \\
\hline
\end{tabular}

Reliability Statistics
\begin{tabular}{|l|l|}
\hline Cronbach's Alpha & N of Items \\
\hline .891 & 27 \\
\hline
\end{tabular}

a. Listwise deletion based on all variables in the procedure.

\section{T-Test Result}

In addition, one sample mean t-test was used to identify those significant variables among the four variables used for the study. In each variable different likert type questions were developed. Respondents were required to provide their level of agreement through choosing one among the five options given from Strongly disagree to Strongly Agree. 1 represents strongly disagree, 2 for disagree, 3 for neutral, 4 for agree and 5 for strongly agree. Once the data were collected it have been organized and codded through the help of Stastical Software Package for Social Science /IBM SPSS Statistics 20/. The result of the study is presented as follows in line with the hypotheses proposed.

As stated above four variables has been identified; namely individual characteristics, immediate environment, general environment and corporate policy. All of the variables found to be significant at $5 \%$ level of significance.

\section{One-Sample Statistics}

\begin{tabular}{|l|l|l|l|l|}
\hline & $\mathrm{N}$ & Mean & Std. Deviation & Std. Error Mean \\
\hline IndMean & 384 & 4.6280 & .40408 & .05715 \\
ComMean & 384 & 4.3300 & .72393 & .10238 \\
GenMean & 384 & 3.3980 & .48252 & .06824 \\
CorMean & 384 & 3.5834 & .45487 & .06433 \\
\hline
\end{tabular}




\section{One-Sample Test}

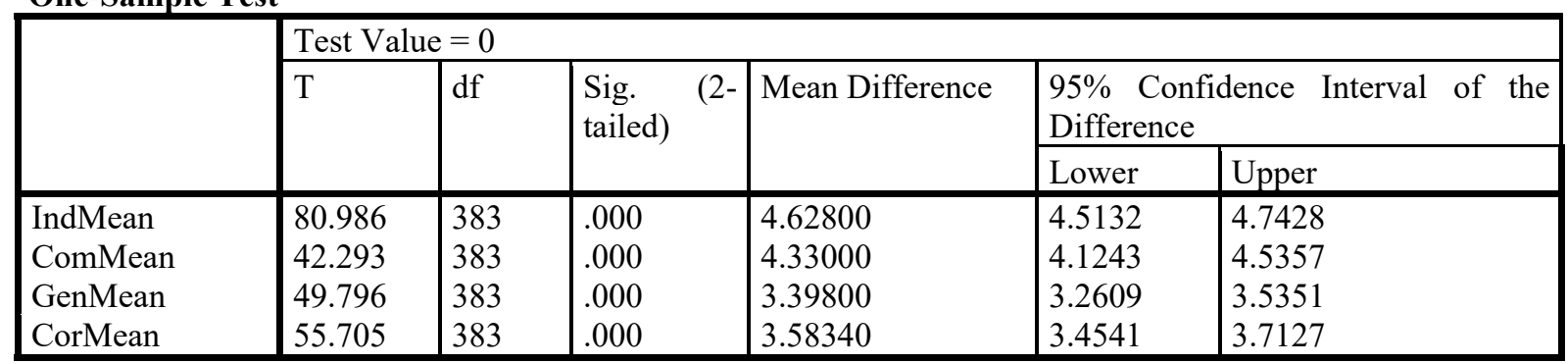

Ho1: Individual variables associated with the entrepreneur make no difference on business failure.

For likert type questions developed for this study, a respondent who disagrees with the issue raised will select either 1 or 2 , and a one who agrees chooses will select either 4 or 5 . If the respondent found to be indifferent which means if she believes the issue raised has no difference a respondent selects 3 . Thus the "neutral, response shows the respondent is indifferent to conclude either to agree/disagree. Because of this reason this point has served us a bench mark to test the level of significance for each questions.

As of Table 4.3. below all likert type questions used to measure individual characteristics/Motivations, managerial skills, knowledge \& experience, and fear of failure/ of a woman were statistically significant at $5 \%$ level of significance. Which means respondents believe that individual variables do have an effect on women entrepreneurs' business failure/success.

Table 4.3. Individual Variables

\section{One-Sample Statistics}

\begin{tabular}{|l|l|l|l|l|}
\hline & $\mathrm{N}$ & Mean & Std. Deviation & Std. Error Mean \\
\hline Individual reason & 384 & 4.92 & .274 & .039 \\
IndV2 & 384 & 4.68 & .819 & .116 \\
IndV3 & 384 & 4.78 & .545 & .077 \\
IndV4 & 384 & 4.76 & .517 & .073 \\
IndV5 & 384 & 4.00 & .639 & .090 \\
\hline
\end{tabular}

\section{One-Sample Test}

\begin{tabular}{|c|c|c|c|c|c|c|}
\hline & \multicolumn{6}{|c|}{ Test Value $=3$} \\
\hline & \multirow[t]{2}{*}{$\mathrm{T}$} & \multirow[t]{2}{*}{ Df } & \multirow[t]{2}{*}{ Sig. (2-tailed) } & \multirow[t]{2}{*}{$\begin{array}{l}\text { Mean } \\
\text { Difference }\end{array}$} & \multicolumn{2}{|c|}{$\begin{array}{l}95 \% \text { Confidence Interval of the } \\
\text { Difference }\end{array}$} \\
\hline & & & & & Lower & Upper \\
\hline Individual reason & 49.540 & 384 & .000 & 1.920 & 1.84 & 2.00 \\
\hline IndV2 & 14.502 & 384 & .000 & 1.680 & 1.45 & 1.91 \\
\hline IndV3 & 23.074 & 384 & .000 & 1.780 & 1.62 & 1.94 \\
\hline IndV4 & 24.051 & 384 & .000 & 1.760 & 1.61 & 1.91 \\
\hline IndV5 & 11.068 & 384 & .000 & 1.000 & .82 & 1.18 \\
\hline
\end{tabular}

The second variable identified to have an effect on women entrepreneurs business failure is the immediate environment which is concerned with customers, suppliers and the level of competition among firms and access to finance. Accordingly all factors are significant at 5\% level of significance and thus these variables have an effect on women entrepreneurs' business failure.

Table 4.4. Immediate environment

One-Sample Statistics

\begin{tabular}{|l|l|l|l|l|}
\hline & $\mathrm{N}$ & Mean & Std. Deviation & Std. Error Mean \\
\hline Competition & 384 & 4.56 & .812 & .115 \\
ComV2 & 384 & 3.88 & .659 & .093 \\
ComV3 & 384 & 4.66 & .872 & .123 \\
ComV4 & 383 & 4.31 & 1.228 & .175 \\
\hline
\end{tabular}




\section{One-Sample Test}

\begin{tabular}{|c|c|c|c|c|c|c|}
\hline & \multicolumn{6}{|c|}{ Test Value $=3$} \\
\hline & \multirow[t]{2}{*}{$\mathrm{T}$} & \multirow[t]{2}{*}{ Df } & \multirow[t]{2}{*}{ Sig. (2-tailed) } & \multirow[t]{2}{*}{$\begin{array}{l}\text { Mean } \\
\text { Difference }\end{array}$} & \multicolumn{2}{|c|}{$\begin{array}{l}95 \% \text { Confidence Interval of the } \\
\text { Difference }\end{array}$} \\
\hline & & & & & Lower & Upper \\
\hline $\begin{array}{l}\text { Competition } \\
\text { ComV2 } \\
\text { ComV3 } \\
\text { ComV4 }\end{array}$ & $\begin{array}{l}13.582 \\
9.442 \\
13.468 \\
7.444 \\
\end{array}$ & $\begin{array}{l}383 \\
383 \\
383 \\
383 \\
\end{array}$ & $\begin{array}{l}.000 \\
.000 \\
.000 \\
.000\end{array}$ & $\begin{array}{l}1.560 \\
.880 \\
1.660 \\
1.306\end{array}$ & $\begin{array}{l}1.33 \\
.69 \\
1.41 \\
.95\end{array}$ & $\begin{array}{l}1.79 \\
1.07 \\
1.91 \\
1.66\end{array}$ \\
\hline
\end{tabular}

The third variable which have an effect on women entrepreneurs' business failure is the General Environments, which describes infrastructure availability, economic situations, technological, legal, and socio cultural factors. As of Table 4.5. Inflation, technology, social \& cultural factors are stastically significant and affect women entrepreneurs' failure. And availability of infrastructure and government incentives were found to be stastically insignificant.

Table 4.5. General Environment

One-Sample Statistics

\begin{tabular}{|l|l|l|l|l|}
\hline & $\mathrm{N}$ & Mean & Std. Deviation & Std. Error Mean \\
\hline General environment & 384 & 2.92 & .900 & .127 \\
GenV2 & 384 & 3.56 & .972 & .137 \\
GenV3 & 384 & 3.56 & .884 & .125 \\
GenV4 & 383 & 4.31 & 1.176 & .168 \\
GenV5 & 384 & 4.70 & .614 & .087 \\
GenV6 & 383 & 1.39 & .931 & .133 \\
GenV7 & 384 & 1.44 & 1.053 & .149 \\
GenV8 & 384 & 3.84 & .912 & .129 \\
GenV9 & 383 & 4.61 & .909 & .130 \\
GenV10 & 4.06 & .385 & .056 \\
GenV11 & 382 & 2.96 & .856 & .121 \\
\hline
\end{tabular}

\section{One-Sample Test}

\begin{tabular}{|l|l|l|l|l|l|l|}
\hline & \multicolumn{5}{|l|}{ Test Value =3 } \\
\cline { 3 - 7 } & T & Df & Sig. (2-tailed) & $\begin{array}{l}\text { Mean } \\
\text { Difference }\end{array}$ & $\begin{array}{l}\text { 95\% Confidence Interval of the } \\
\text { Difference }\end{array}$ \\
\cline { 3 - 7 } & & & & & Lower & Upper \\
\hline General environment & -.629 & 383 & .533 & -.080 & -.34 & .18 \\
GenV2 & 4.073 & 383 & .000 & .560 & .28 & .84 \\
GenV3 & 4.478 & 383 & .000 & .560 & .31 & .81 \\
GenV4 & 7.773 & 383 & .000 & 1.306 & .97 & 1.64 \\
GenV5 & 19.563 & 383 & .000 & 1.700 & 1.53 & 1.87 \\
GenV6 & -12.118 & 383 & .000 & -1.612 & -1.88 & -1.34 \\
GenV7 & -10.477 & 383 & .000 & -1.560 & -1.86 & -1.26 \\
GenV8 & 6.516 & 383 & .000 & .840 & .58 & 1.10 \\
GenV9 & 12.420 & 383 & .000 & 1.612 & 1.35 & 1.87 \\
GenV10 & 18.957 & 383 & .000 & 1.064 & .95 & 1.18 \\
GenV11 & -.330 & 383 & .743 & -.040 & -.28 & .20 \\
\hline
\end{tabular}

The fourth variable having an effect on business failure is the corporate policy. To measure this variable seven likert type questions were developed. The seven questions were related to the existence of marketing strategy, human resource strategy, financing strategy, motivational strategies, availability of labor at lower cost, cooperation with partners, and withdrawal of partners. The result depicts existence of marketing strategy, financing strategy incentives to motivate employees, and cooperation among partners are stastically significant at 5\% level of significance thus the have an effect on business failure. However, withdrwal of a partners is not a significant variable. 
Table 4.5. Corporate Policy

One-Sample Statistics

\begin{tabular}{|l|l|l|l|l|}
\hline & $\mathrm{N}$ & Mean & Std. Deviation & Std. Error Mean \\
\hline Corprate policy & 383 & 3.94 & .517 & .074 \\
CorV2 & 384 & 2.96 & .727 & .103 \\
CorV3 & 384 & 3.84 & .584 & .083 \\
CorV4 & 384 & 4.44 & 1.033 & .146 \\
CorV5 & 383 & 3.04 & .771 & .111 \\
CorV6 & 383 & 4.00 & .577 & .082 \\
CorV7 & 383 & 2.85 & .684 & .099 \\
\hline
\end{tabular}

One-Sample Test

\begin{tabular}{|l|l|l|l|l|l|l|}
\hline & \multicolumn{2}{|l|}{ Test Value =3 } \\
\cline { 3 - 7 } & T & Df & Sig. (2-tailed) & $\begin{array}{l}\text { Mean } \\
\text { Difference }\end{array}$ & $\begin{array}{l}\text { 95\% Confidence Interval of the } \\
\text { Difference }\end{array}$ \\
\cline { 3 - 7 } & & & & & Lower & Upper \\
\hline Corprate policy & 12.717 & 48 & .000 & .939 & .79 & 1.09 \\
CorV2 & -.389 & 49 & .699 & -.040 & -.25 & .17 \\
CorV3 & 10.168 & 49 & .000 & .840 & .67 & 1.01 \\
CorV4 & 9.854 & 49 & .000 & 1.440 & 1.15 & 1.73 \\
CorV5 & .375 & 47 & .710 & .042 & -.18 & .27 \\
CorV6 & 12.124 & 48 & .000 & 1.000 & .83 & 1.17 \\
CorV7 & -1.477 & 47 & .146 & -.146 & -.34 & .05 \\
\hline
\end{tabular}

\section{Conclusion \& Recommendations}

The following conclusions are drawn from the findings presented above

$>$ Most entrepreneurship studies have been conducted focused on successful ventures. As indicated in several studies, a deep understanding of new venture failures in a different context would provide critical information for individual entrepreneurs, venture financiers, and government policymakers. The finding of this study shows that causes of business failure are associated with individual characteristics, corporate policy, immediate environment and general environment.

$>$ Among individual characteristics motivation, managerial skills, knowledge and experience and fear of failure are found to be the major causes of business failure.

\section{Bibliography}

1. Bekele, Eshetu and Worku, Zeleke (2008). Women Entrepreneurship in Micro, Small and Medium Enterprises: The Case of Ethiopia. Journal of International Women's Studies, 10(2), 3-19.

2. Kebede, B. (2002). Land tenure and common pool resources in rural Ethiopia: a study based on fifteen sites. Journal of African Development Review, 14(1), 4-9.

3. Ethiopian Economic Association. (2004). Industrialization and Industrial Policy in Ethiopia: Report on Ethiopian Economy, Volume III. Addis Ababa: Ethiopian Economic Association.

4. Hisrich, R.D. (2005). Entrepreneurship. 7th Edition, Boston: McGraw Hill.

5. Schumpeter, J (2005). The theory of economic development. Cambridge Mass.: Harvard University Press.

6. Eshetu, B. and Zeleke, W. (2008).Women entrepreneurship in micro, small and medium enterprises: The case of Ethiopia. Journal of international women'sstudies.Vol.10\#2Nov (pp.3-5)

7. Hisrich, R.D. (2005), Entrepreneurship.7th Edition, Boston: McGraw Hill. Retrieved on 15-5

8. Samiti, V. (2006).A research study on Entrepreneurial Challenges for SC Persons inIndia. New Delhi: Planning Commission Government of India YojanaBhawan.

9. Desta Solomon (2010), Desk Review of studies conducted on women Entrepreneurs in Ethiopia.

10. GemechisTefera. (2007).Attitude Of College Students Towards Entrepreneurship:ACase Study of Addis Ababa University and Rift Valley University College. AddisAbaba, Ethiopia. Unpublished Thesis

11. UNIDO.(2001). Women Entrepreneurship Development in Selected African Countries.Working Paper No.7.Legos

12. UNECE. (2004). “Women's Self Employment and Entrepreneurship in the ECE region”,background paper prepared by the secretariat for the RegionalSymposium onMainstreaming Gender into Economic Policies, Geneva, and 28-30 January 2004

13. OECD (1997), Entrepreneurship and SMEs in Transitional Economies, the VisegradConference, OECD Proceedings, Paris.OECD (2002).The Keys for Successful Women Entrepreneurs. The OECD 
BolognaProcess, December 2002.

14. Hadiya Mohammed. (1998). Sharing Experiences: Success Stories of WomenEntrepreneurs.Addis Ababa. Unpublished.

15. ILO.(2008).Women Entrepreneurs in Kenya.Factors affecting Women Entrepreneurs inMicro and Small Enterprises in Kenya. Geneva. International labor Organization.

16. Morris, M.H., Miyasaki, N.N., Watters, C.E. and Coombes, S.M. (2006), "The Dilemma of growth, Understanding Venture Size choices of women entrepreneurs", Journal of Small Business Management, 44(2), pp. 221-244

17. Yordanova, D.I. (2011), "The effects of Gender on Entrepreneurship in Bulgaria: An Empirical Study", International Journal of Management, Vol. 28 No1, Part 2. 